\title{
FAKTOR - FAKTOR YANG MEMPENGARUHI CUSTOMER LOYALTY PADA KONSUMEN REKSADANA AUTOINVEST DI BANK COMMONWEALTH JAKARTA
}

\author{
Rr Renny Anggraini ${ }^{1)}$ \\ ${ }^{1)}$ dosen universitas pamulang, email : dosen01802@unpam.ac.id
}

\section{ARTICLES}

INFORMATION

ABSTRACT

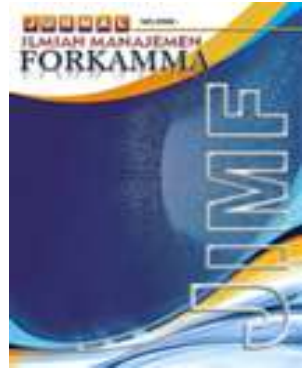

\section{JURNAL ILMIAH MANAJEMEN FORKAMMA}

Vol.2, No.2, Maret 2019 Halaman : $83-95$

(C) LPPM \& FORKAMMA

Prodi Magister Manajemen

UNVERSITAS PAMULANG

ISSN (online) : 2599-171X

ISSN (print) : :2598-9545

Keyword :

Perceived Quality, Brand Loyalty, Brand Association, Brand Trust, Customer Loyalty

JEL. classification :

C33, G20, G23, N65

\section{Contact Author :}

PRODI
MAGISTER MANAJEMEN \&
FORKAMMA UNPAM
JL.Surya Kencana No.1 Pamulang
Tangerang Selatan - Banten
Telp. (021) 7412566, Fax (021) 7412491
Email :
uurnalforkamma.unpam@gmail.com

Penelitian ini bertujuan untuk menjelaskan kekuatan dari loyalitas konsumen. Sangat penting untuk mengetahui bahwa loyalitas konsumen menjadi bagian dari pemasaran yang memiliki pengaruh untuk membuat persaingan usaha dan membangun kekuatan dalam pengalaman konsumen untuk membuat suatu keputusan pembelian produk.

Objek dari penelitian ini adalah untuk menganalisis pengaruh kualitas manfaat pada loyalitas konsumen, pengaruh loyalitas merk pada loyalitas konsumen, pengaruh asosiasi merek pada loyalitas konsumen, dan pengaruh kepercayaan merek pada loyalitas konsumen.

Hasil dari penelitian ini menyatakan bahwa terdapat pengaruh positif dari kualitas manfaat pada loyalitas konsumen, pengaruh positif dari loyalitas merek pada loyalitas konsumen, pengaruh positif dari asosiasi merek pada loyalitas konsumen, dan pengaruh positif dari kepercayaan merek pada loyalitas konsumen.

The background of this research was examined the strength of customer loyalty. It is imperative to knowledge that customer loyalty is an separable part of marketing and essential to the companies to create core-competencies and build strong customer experience that will impact the consumer decision making process.

The objectives of this research is to analyze the influence of Perceived Quality on Customer Loyalty, the influence of Brand Loyalty on Customer Loyalty, the influence of Brand Association on Customer Loyalty, and the influence of Brand Trust on Customer Loyalty.

The result of this research conclude that the effect positively of Perceived Quality on Customer Loyalty, the effect positively of Brand Loyalty on Customer Loyalty, the effect positively of Brand Association on Customer Loyalty, the effect positively Brand Trust on Customer Loyalty. 


\section{A. Pendahuluan}

Sejalan dengan perkembangan perekonomian Indonesia yang demikian cepat, sektor perbankan mengalami kemajuan yang sangat pesat. Berbagai kebijakan dikeluarkan pemerintah dalam rangka meningkatkan kegiatan perbankan dalam usahanya menyalurkan dana masyarakat sesuai dengan fungsi perbankan. Bisnis perbankan merupakan bisnis jasa yang memberikan tingkat kepercayaan kepada pelanggannya yakni nasabah bank. Bank dituntut untuk mampu memberikan pelayanan berkualitas yang dapat memenuhi kebutuhan dan keinginan nasabahnya selain menawarkan berbagai macam jenis produk dan jasa layanannya.

Persaingan antar perbankan di Indonesia sudah sangat ketat akhir-akhir ini. Memenangkan persaingan dalam industri perbankan tidaklah mudah, setiap bank harus menciptakan dan memberikan nilai yang sangat unggul kepada para pelanggan. Persaingan ini dapat dianggap menguntungkan konsumen dan dianggap dapat membuat persaingan perbankan lebih kompetitif.

Aaker (2000) menyatakan merek dapat dijadikan salah satu sumber keunggulan bersaing. Memiliki dan melahirkan merek yang besar dan kuat tentu menjadi idaman semua pelaku bisnis. Dengan kekuatan merek yang besar akan memudahkan perusahaan meraup pendapatan dan memberi jaminan masa depan untuk jangka panjang. Kendati demikian proses membangun dan melahirkan merek yang besar tidak sangat tidak mudah. Tak sedikit pemasar yang telah menanamkan puluhan miliyar untuk investasi pengembangan merek ternyata gagal. Bukan saja tidak bisa membuat mereknya menjadi besar, tetapi malah berujung pada kematian merek (Temporal dan KC Lee, 2001).

Berhasil atau tidaknya produk tersebut dipasaran tergantung dari keahlian pihak perusahaan dalam mengkombinasikan fungsi - fungsi pemasaran. Pemasaran dapat dikatakan sebagai suatu sistem keseluruhan dari kegiatan - kegiatan yang ditujukan untuk merencanakan, menentukan harga produk yang ditawarkan, kegiatan promosi dan tempat untuk mendistribusikan produk, termasuk kepuasan yang dirasakan oleh konsumen. Jika pemasaran atas suatu produk sudah baik, masih ada faktor lain yang menentukan sukses tidaknya produk tersebut dipasaran. Salah satunya adalah bagaimana perusahaan menciptakan dan memelihara suatu merek (brand).

Pada umumnya merek seringkali dijadikan sebagai objek loyalitas pelanggan. Loyalitas merek (Brand Loyalty) mencerminkan loyalitas pelanggan pada merek tertentu. Loyalitas merek merupakan suatu kondisi dimana konsumen memiliki sikap yang positif terhadap merek, memiliki komitmen terhadap merek, dan memiliki kecenderungan untuk meneruskan pembeliannya di masa yang akan datang. Menurut Shergill dan Li (2005), kepercayaan (trust) akan mempengaruhi loyalitas nasabah pada fasilitas bank yang pada akhirnya juga loyal terhadap bank yang bersangkutan. Menurut Floh dan Treiblmaier (2006) mengatakan bahwa kepuasan dan kepercayaan mempengaruhi loyalitas nasabah. Nasabah selalu menilai suatu layanan yang diterima dibandingkan dengan apa yang diharapkan atau diinginkan (Parasuraman et al., 1993).

Brand equity adalah satu set brand asset dan kewajiban yang berkaitan dengan suatu merek, nama dan simbolnya, yang menambah atau mengurangi nilai yang diberikan oleh sebuah barang atau jasa kepada perusahaan atau para pelanggan perusahaan. Ekuitas merek merupakan nilai tambah yang diberikan pada produk dan jasa. Ekuitas merek dapat tecermin dalam cara konsumen berpikir, merasa, dan bertindak dalam hubungannya dengan merek, dan juga harga, pangsa pasar, serta profitabilitas yang diberikan merek bagi perusahaan. Ekuitas merek dapat menguatkan program memikat para konsumen baru atau menarik kembali konsumen yang sudah ada. Promosi yang dilakukan akan lebih efektif jika mereka itu dikenal dan dapat menghilangkan kebimbangan konsumen terhadap kualitas merek. Ekuitas merek dapat mempengaruhi alasan pembelian konsumen dan dapat mempengaruhi kepuasan penggunaan. Selain itu juga dapat mengurangi keinginan konsumen untuk mencoba 
merek lain. Pembentukan ekuitas merek dapat menciptakan manajemen merek yang efektif (Pappu, Quester, dan Cooksey, 2006). Keller (2009) menyatakan bahwa ekuitas merek atau brand equity berasal dari konsumen, sehingga seringkali disebut sebagai Customer-Based Brand Equity (CBBE). CBBE muncul ketika konsumen memiliki tingkat kesadaran dan keakraban yang tinggi dengan sebuah brand dan memiliki asosiasi yang kuat dan unik terhadap brand tersebut dalam pikirannya.

Reksadana Autolnvest merupakan salah satu produk unggulan investasi dari Commonwealth Bank. Dimana setiap keinginan nasabah untuk berinvestasi dapat terpenuhi. Apapun tujuan dan kebutuhan financial nasabah, tim Wealth Management yang ada pada perusahaan Commonwealth Bank yang memiliki dukungan akses 24 jam untuk riset pasar global, akan membantu untuk mewujudkan semua impian dan harapan nasabah mengenai investasi. Pengalaman memiliki reksadana Autolnvest akan menjadi suatu awal untuk memiliki perencanaan yang baik mengenai masa depan nasabah dan keluarganya.

Berdasarkan penjelasan di atas, maka penulis akan melakukan penelitian yang berjudul: "Faktor - faktor yang Mempengaruhi Customer Loyalty pada Konsumen Reksadana Autolnvest di Bank Commonwealth Jakarta".

\section{B. Perumusan Masalah}

1) Bagaimana pengaruh positif perceived quality pada customer loyalty?

2) Bagaimana pengaruh positif brand loyalty pada customer loyalty?

3) Bagaimana pengaruh positif brand association pada customer loyalty?

4) Bagaimana pengaruh positif brand trust pada customer loyalty?

\section{Tujuan Penelitian}

1) Untuk mengetahui bagaimana pengaruh postif perceived quality pada customer loyalty

2) Untuk mengetahui bagaimana pengaruh postif brand loyalty pada customer loyalty

3) Untuk mengetahui bagaimana pengaruh positif brand association pada customer loyalty

4) Untuk mengetahui bagaimana positif brand trust pada customer loyalty

\section{Landasan Teori}

Anuwichanont dan Mechinda (2009) mendefinisikan Perceived Value adalah suatu penilaian yang dilakukan oleh para pelanggan mengenai kegunaan dari suatu produk atau jasa untuk menilai apa yang diterima dan apa yng diberikan oleh perusahaan penyedia jasa. Aurier dan Lanauze (2011) memberikan pengertian Perceived Value adalah suatu evaluasi yang dilakukan oleh pelanggan ketika mengkonsumsi dan membeli suatu produk atau jasa. Boksberger dan Melsen (2011) memberikan pengertian Perceived Value adalah suatu evaluasi yang dilakukan oleh pelanggan terhadap manfaat yang diterima pelanggan ketika menggunakan produk atau jasa dengan pengorbanan yang dikeluarkan oleh nasabah. Chang dan Wang (2011) juga mendefinisikan Perceived Value adalah suatu perbandingan antara apa yang diterima pelanggan dengan apa yang diberikan oleh perusahaan penyedia jasa.

Berdasarkan penjelasan para pakar diatas diartikan bahwa Perceived Value adalah suatu penilaian yang dilakukan oleh nasabah dengan cara membandingkan antara manfaat atau keuntungan yang akan diterima dengan pengorbanan yang dikeluarkan untuk memperoleh suatu produk atau jasa.

Edward dan Sahadev (2011) menjelaskan mengenai tujuan dari pembentukan Perceived Value adalah untuk membandingkan antara manfaat yang diperoleh nasabah dengan biaya yang dikeluarkan oleh nasabah ketika membeli produk atau jasa. Jen, Tu, dan Lu (2011) menyatakan bahwa tujuan dari Perceived Value adalah untuk menciptakan keunggulan kompetitif yang dimiliki oleh perusahaan. 
Menurut Schiffman dan Kanuk (2009), loyalitas merek adalah pilihan konsumen secara konsisten untuk melakukan pembelian pada merek yang sama pada produk yang spesifik atau kategori pelayanan tertentu. Jika konsumen sudah mencapai tahap loyalitas, berarti mereka bersedia membayar dengan harga premium, dan tidak mau memakai merek lain. Brand loyalty juga merupakan suatu ukuran keterkaitan konsumen kepada suatu merek. Ukuran ini menggambarkan tentang mungkin tidaknya konsumen beralih ke prosuk lain, terutama jika pada merek tersebut didapati adanya perubahan. Konsumen yang loyal umumnya akan melanjutkan penggunaan merek tersebut walaupun dihadapkan dengan banyak alternatif merek produk pesaing yang menawarkan karakteristik produk yang lebih unggul.

Chahal dan Bala (2010) menyebutkan tujuan menciptakan loyalitas merek adalah untuk meningkatkan ekuitas merek produk atau jasa. Chaudhuri dan Holbrook (2001) menyebutkan tujuan menciptakan loyalitas merek adalah untuk menciptakan keinginan dari dalam diri konsumen untuk membayar dengan harga yang lebih tinggi dari merek produk atau jasa yang dijual oleh perusahaan.

Holland dan Baker (2001) mengukur brand loyalty dengan menggunakan indikator yaitu pola pembelian secara aktual yang dimiliki oleh para pelanggan. Moisescu (2011) beranggapan bahwa brand loyalty sebagai brand strength yang merupakan hasil dari terciptanya brand awareness dan brand strength. Moisescu (2011) mengklasifikasikan penilaian terhadap loyalitas merek terbagi ke dalam penilaian sikap dan penilaian perilaku. Penilaian terhadap sikap pelanggan (Attitudinal) ditunjukkan dengan adanya penilaian terhadap kesukaan, komitmen dan rencana pembelian yang dimiliki oleh para pelanggan (Moisescu, 2011). Penilaian terhadap perilaku pelanggan (behavioral) ditunjukkan dengan adanya pembelian secara aktual selama periode waktu tertentu (Moisescu, 2011). Moisescu dan Allen (2010) menjelaskan mengenai pengukuran loyalitas merek agar efisien untuk meningkatkan profitabilitas perusahaan. Adanya prosedur pengukuran loyalitas merek dapat terbagi dua yaitu sikap dan perilaku. Pengukuran loyalitas merek berdasarkan sikap dengan melihat kesukaan pelanggan, komitmen pelanggan, dan rencana pembelian yang dimiliki pelanggan. Pengukuran loyalitas merek berdasarkan perilaku dengan melihat pembelian secara aktual dalam suatu periode tertentu (Moisescu dan Allen, 2010).

Menurut Aaker (1997) asosiasi merek adalah segala hal yang berkaitan dengan ingatan mengenai merek, atau dengan kata lain segala kesan yang muncul di benak seseorang terkait denagn ingatannya mengenai suatu merek. Nilai yang mendasari merek seringkali didasarkan pada asosiasi - asosiasi spesifik yang berkaitan dengannya.

Trust dianggap sebagai suatu perkataan, janji, pernyataan verbal atau pernyataan tertulis dari suatu individu pada individu lainnya (Kantsperger dan Kunz, 2010). Trust adalah suatu keyakinan nasabah terhadap perusahaan mengenai kehandalan dan integritas yang dimiliki oleh perusahaan (Guenzi et al., 2009). Menurut Kesharwani dan Bisht (2012), trust adalah suatu keyakinan dari pelanggan terhadap tindakan yang dilakukan oleh suatu perusahaan penyedia jasa. Kamtarin (2012) menyebutkan pengertian trust adalah suatu keyakinan pelanggan terhadap apa yang diharapkan oleh perusahaan penyedia jasa. Kepercayaan merek merupakan variabel psikologis yang mencerminkan sejumlah akumulasi awal yang melibatkan kredibilitas dan integritas yang dilekatkan pada merek tertentu.

Dalam konteks teori behavior, Palilati (2004) menguraikan bahwa kepuasan lebih banyak didefinisikan dari perspektif pengalaman konsumen setelah mengkonsumsi atau menggunakan suatu produk atau jasa. Kepuasan pelanggan dalam industri jasa perbankan menurut Nauman dan Giell (1995) dapat diukur berdasarkan indikator perasaan nasabah yang dikembangkan dari dimensi kinerja jasa, beban biaya, citra perusahaan, dan keputusan menggunakan jasa layanan bank.

Loyalitas terhadap produk/jasa perusahaan (merek) didefinisikan sebagai sikap menyenangi (favorable) terhadap suatu merk, yang dipresentasikan dalam pembelian 
yang konsisten terhadap merek itu sepanjang waktu. Menurut Gale (1997), dalam Palilati (2004) mengatakan bahwa tingkat loyalitas pelanggan dipengaruhi oleh persepsi konsumen terhadap nilai yang ditawarkan oleh suatu perusahaan.

Nilai pelanggan menunjukkan adanya persepsi konsumen mengenai apa yang diterima dibandingkan dengan apa yang diberikan oleh perusahaan penyedia jasa (Anuwichanont dan Mechinda, 2009). Loyalitas pelanggan terbentuk melalui pembentukan keadilan di dalam penyampaian layanan jasa kepada pelanggan (Lee, Joshi, dan Kim, 2011). Persepsi mengenai nilai yang diterima oleh pelanggan menjadi salah satu alasan untuk melakukan transaksi pada suatu perusahaan penyedia jasa (Sabiote et al., 2012).

Menurut pengungkapan (Dyson et al., 1996; Franzen, 1999; Keller, 2001a, b, 2008) terdapat hubungan antara empat dimensi nilai yang dirasakan yaitu (perceived quality, brand loyalty, brand association, dan brand trust) terhadap customer loyalty. Kotler (1995) mengatakan bahwa kualitas adalah total dari seluruh fitur dan karakteristik yang membuat produk dapat memuaskan kebutuhan, baik yang dinyatakan maupun yang tidak dinyatakan. Dalam literatur - literatur pemasaran, istilah kualitas mempunyai ruang lingkup yang beragam. Zeithaml (1988) mengemukakan bahwa kualitas dalam pandangan konsumen (perceived quality) adalah yang mempunyai ruang lingkup tersendiri yang berbeda dengan kualitas dalam pandangan produsen saat mengeluarkan suatu produk yang biasa dikenal dengan kualitas sebenarnya. Kualitas dalam pandangan konsumen lebih merupakan respon subjektif konsumen terhadap fenomena produk sehingga cenderung relatif.

Dari hasil penelitian terdahulu terdapat gap atau gap research untuk itu penulis mengambil hipotesis dari peneltian ini adalah sebagai berikut:

$\mathrm{H}_{1}$ : Terdapat pengaruh yang positif antara Perceived quality dan Customer loyalty

$\mathrm{H}_{2}$ : Terdapat pengaruh yang positif antara Brand loyalty dan Customer loyalty

$\mathrm{H}_{3}$ : Terdapat pengaruh yang positif antara Brand association dan Customer loyalty

$\mathrm{H}_{4}$ : Terdapat pengaruh yang positif antara Brand trust dan Customer loyalty






\section{E. Metodologi}

Objek dalam penelitian ini adalah Bank Commonwealth Jakarta. Subjek penelitiannya adalah nasabah Bank Commonwealth Jakarta yang memiliki autoinvest di Bank Commonwealth Jakarta. Penelitian ini dilakukan untuk mengetahui pengaruh Perceived Quality terhadap Customer Loyalty, pengaruh Brand Loyalty terhadap Customer Loyalty, pengaruh Brand Association terhadap Customer Loyalty dan pengaruh Brand Trust terhadap Customer Loyalty. Dalam penelitian ini, sampel penelitian mengacu pada nasabah yang memiliki produk Reksadana Autolnvest Commonwealth Bank yang berlokasi di Jakarta. pengambilan sampel dalam penelitian ini dilakukan dengan cara menyebarkan kuesioner kepada 100 nasabah yang memiliki produk Reksadana Autolnvest Commonwealth Bank dari 134 nasabah nasabah yang memiliki produk Reksadana Autolnvest Commonwealth Bank sebagai populasi yang ada.

Teknik pengumpulan sampel yang digunakan dalam penelitian ini dilakukan secara purposive sampling yaitu penarikan sampel berdasarkan pada pertimbanganpertimbangan tertentu, dimana sampel yang dipilih berdasarkan pada kriteria-kriteria tertentu (Sekaran, 2006) yang sesuai dengan kriteria penelitian.

Metode pengumpulan data yang penulis gunakan adalah melalui studi pustaka (library research) dan studi lapangan (field research). Untuk memperoleh data yang relevan, akurat, dan reliable dalam penelitian ini menggunakan dua macam sumber data yaitu sumber primer dan sumber sekunder.

\section{F. Hasil Dan Pembahasan}

\section{Karakteristik responden}

Obyek dari penelitian ini adalah nasabah yang memiliki produk Reksadana Autolnvest Commonwealth Bank. Sampel yang diambil sebanyak 100 responden, dari data yang diperoleh mengenai responden dapat diklasifikasikan sebagai berikut:

\section{Tabel 1.}

Profil Responden

\begin{tabular}{|l|l|c|c|}
\hline No & \multicolumn{1}{|c|}{ Profil Responden } & Jumlah & $\begin{array}{c}\text { Persentase } \\
(\%)\end{array}$ \\
\hline 1. & Jenis Kelamin: & 42 & $42 \%$ \\
& a. Pria & 58 & $58 \%$ \\
\hline $2 . \quad$ blasan nasabah percaya terhadap reksadana & & \\
& Autolnvest dari Commonwealth Bank: & 12 & $12 \%$ \\
& a. Layanan Berkelas & 54 & $54 \%$ \\
& b. Saran yang diberikan sesuai dengan kebutuhan & & \\
& cinansial nasabah & 34 & $34 \%$ \\
& c. Personalisasi informasi yang diberikan kepada & & \\
\hline 3. & Pendidikan Terakhir: & 26 & $26 \%$ \\
& a. Diploma 3 (D3) & 43 & $43 \%$ \\
& b. Sarjana Strata 1 (S1) & 29 & $29 \%$ \\
& c. Pasca Sarjana (S2) & 2 & $2 \%$ \\
\hline d. Lainnya... & Lama menjadi nasabah Commonwealth Bank: & 32 & $32 \%$ \\
& a. 2 - 3 Tahun & 43 & $43 \%$ \\
& b. 4 - 5 Tahun & 25 & $25 \%$ \\
\hline
\end{tabular}


Pada tabel 1 terlihat karakteristik demografis dari responden dimana responden yang berjenis kelamin pria sejumlah 42 responden atau ditunjukkan berdasarkan persentase sejumlah 42 persen (42\%), sedangkan nasabah yang memiliki jenis kelamin wanita sebanyak 58 responden ditunjukkan berdasarkan persentase sejumlah 58 persen $(58 \%)$.

Karakteristik demografis dari responden yang memiliki alasan nasabah percaya terhadap reksadana Autolnvest dari Commonwealth bank karena layanan berkelas adalah sebanyak 12 responden atau ditunjukkan berdasarkan persentase diperoleh sebesar 12 persen (12\%). Saran yang diberikan sesuai dengan kebutuhan finansial nasabah diperoleh sebanyak 54 responden atau berdasarkan persentase diperoleh sebesar 54 persen (54\%). Personalisasi informasi yang diberikan kepada nasabah sangat akurat diperoleh sebanyak 34 responden atau berdasarkan persentase diperoleh sebesar 34 persen (34\%).

Karakteristik demografis dari responden yang memiliki pendidikan terakhir Diploma 3 (D3) sebanyak 26 responden atau ditunjukkan berdasarkan persentase diperoleh sebesar 26 persen (26\%). Nasabah yang memiliki pendidikan terakhir Sarjana Strata 1 (S1) sebanyak 43 responden atau ditunjukkan berdasarkan persentase diperoleh sebesar 43 persen (43\%), nasabah yang memiliki pendidikan terakhir Sarjana Strata 2 (S2) sebanyak 29 responden atau ditunjukkan berdasarkan persentase diperoleh sebesar 29 persen (29\%) dan lainnya sebanyak 2 responden atau ditunjukkan berdasarkan persentase diperoleh sebesar 2 persen $(2 \%)$.

Karakteristik demografis dari jangka waktu responden menjadi nasabah Commonwealth bank selama 2-3 Tahun diperoleh sebesar 32 responden atau ditunjukkan berdasarkan persentase diperoleh sebesar 32 persen (32\%). Responden yang jangka waktu menjadi nasabah Commonwealth bank selama 4-5 Tahun diperoleh sebesar 43 responden atau ditunjukkan berdasarkan persentase diperoleh sebesar 43 persen (43\%). Responden yang jangka waktu menjadi nasabah Commonwealth bank selama lebih dari 6 Tahun sebesar 25 responden atau ditunjukkan berdasarkan persentase diperoleh sebesar 25 persen (25\%).

Berdasarkan Tabel 1 hasil penelitian mengenai karakteristik responden dilihat dari jenis kelamin, alasan nasabah percaya terhadap reksadana Autolnvest dari Commonwealth Bank, pendidikan terakhir serta lama menjadi nasabah Commonwealth Bank dapat disimpulkan bahwa nasabah reksadana Autolnvest di Commonwealth Bank didominasi oleh wanita, mayoritas responden nasabah reksadana Autolnvest di Commonwealth Bank setuju bahwa saran yang diberikan sesuai dengan kebutuhan finansial nasabah, pendidikan terakhir nasabah reksadana Autolnvest di Commonwealth Bank mayoritas adalah Sarjana Strata 1 (S1). Lama menjadi nasabah Commonwealth Bank mayoritas adalah 4-5 Tahun.

\section{Statistik deskriptif}

Hasil statistik dari variabel-variabel yang diteliti yaitu Perceived Quality, Brand Loyalty, Brand Association, Brand Trust dan Customer Loyalty dapat dilihat pada Tabel 2 di bawah ini

Tabel 2.

Statistik Deskriptif

\begin{tabular}{|l|c|c|c|}
\hline \multicolumn{1}{|c|}{ Variabel } & N & Mean & Std. Deviation \\
\hline Perceived Quality & 100 & 3,9567 & 0,44103 \\
Brand Loyalty & 100 & 3,9100 & 0,42072 \\
Brand Association & 100 & 3,9400 & 0,39747 \\
Brand Trust & 100 & 4,1700 & 0,44820
\end{tabular}


Nilai rata-rata yang paling tinggi dari statistik deskriptif adalah variabel Brand Trust diperoleh rata-rata nilai sebesar 4,1700 , hal tersebut menunjukkan bahwa responden percaya produk reksadana Autolnvest dapat meningkatkan nilai dari produk itu sendiri dengan standar deviasi sebesar 0,44820. Sedangkan nilai rata-rata yang paling rendah dari statistik deskriptif adalah variabel Brand Loyalty diperoleh rata-rata nilai sebesar 3,9100 , hal tersebut menunjukkan bahwa responden percaya produk reksadana Autolnvest dapat meningkatkan nilai dari produk itu sendiri dengan standar deviasi sebesar 0,42072.

Nilai rata-rata dari statistik deskriptif untuk variabel Perceived Quality diperoleh rata-rata nilai sebesar 3,9567, hal tersebut menunjukkan bahwa responden percaya produk reksadana Autolnvest dapat meningkatkan nilai dari produk itu sendiri dengan standar deviasi sebesar 0,44103. Nilai rata-rata dari statistik deskriptif untuk variabel Brand Association diperoleh rata-rata nilai sebesar 3,9400, hal tersebut menunjukkan bahwa responden percaya produk reksadana Autolnvest dapat meningkatkan nilai dari produk itu sendiri dengan standar deviasi sebesar 0,39747. Nilai rata-rata dari statistik deskriptif untuk variabel Customer Loyalty diperoleh rata-rata nilai sebesar 4,1200, hal tersebut menunjukkan bahwa responden percaya produk reksadana Autolnvest dapat meningkatkan nilai dari produk itu sendiri dengan standar deviasi sebesar 0,33002.

3. Hasil uji hipotesis

Hasil uji hipotesis yang ditunjukkan pada Tabel 5 didasarkan pada ketentuan di dalam pengambilan keputusan dalam menguji hipotesis penelitian yaitu:

- Apabila $p$-value<0,05 maka $\mathrm{H}_{0}$ ditolak, Ha diterima yang artinya variabel bebas (Independent Variable) memiliki pengaruh secara positif terhadap variabel terikat (Dependent Variable).

- Apabila $p$-value $>0,05$ maka $\mathrm{H}_{0}$ diterima, $\mathrm{Ha}$ ditolak yang artinya variabel bebas (Independent Variable) tidak memiliki pengaruh secara positif terhadap variabel terikat (Dependent Variable).

Tabel 3.

Hasil Uji Hipotesis

\begin{tabular}{|l|c|c|c|}
\hline \multicolumn{1}{|c|}{ Hipotesis } & $\begin{array}{c}\text { Standardized } \\
\text { Coefficient Beta } \\
\mathbf{( \beta )}\end{array}$ & $\begin{array}{c}\boldsymbol{p} \text { - } \\
\text { value }\end{array}$ & \multicolumn{1}{c|}{ Hasil } \\
\hline $\begin{array}{l}\mathrm{H}_{1}: \text { Terdapat pengaruh yang signifikan } \\
\text { dan positif antara Perceived quality dan } \\
\text { Customer loyalty }\end{array}$ & 0,242 & 0,007 & $\begin{array}{l}\mathrm{Ho}_{1} \text { ditolak, } \\
\mathrm{Ha}_{1} \text { diterima }\end{array}$ \\
\hline $\begin{array}{l}\mathrm{H}_{2}: \text { Terdapat pengaruh yang signifikan } \\
\text { dan positif antara Brand loyalty dan } \\
\text { Customer loyalty }\end{array}$ & 0,200 & 0,015 & $\begin{array}{l}\mathrm{Ho}_{2} \text { ditolak, } \\
\mathrm{Ha}_{2} \text { diterima }\end{array}$ \\
\hline $\begin{array}{l}\mathrm{H}_{3}: \text { Terdapat pengaruh yang signifikan } \\
\text { dan positif antara Brand association dan } \\
\text { Customer loyalty }\end{array}$ & 0,266 & 0,002 & $\begin{array}{l}\mathrm{Ho}_{3} \text { ditolak, } \\
\mathrm{Ha}_{3} \text { diterima }\end{array}$ \\
\hline $\begin{array}{l}\mathrm{H}_{4}: \text { Terdapat pengaruh yang signifikan } \\
\text { dan positif antara Brand trust dan } \\
\text { Customer loyalty }\end{array}$ & 0,282 & 0,001 & $\begin{array}{l}\mathrm{Ho}_{4} \text { ditolak, } \\
\mathrm{Ha}_{4} \text { diterima }\end{array}$ \\
\hline
\end{tabular}

- Hipotesis 1:

- Bunyi hipotesis null $\left(\mathrm{H}_{0}\right)$ dan hipotesis alternatif $\left(\mathrm{H}_{\mathrm{a}}\right)$ adalah sebagai berikut: 
- $\mathrm{H}_{01}$ : Perceived quality tidak berpengaruh positif terhadap Customer loyalty.

- $\mathrm{H}_{\mathrm{a} 1}$ : Perceived quality berpengaruh positif terhadap Customer loyalty.

- Pada pengujian hipotesis 1 diketahui $p$-value 0,007< alpha 0,05 dengan nilai beta sebesar 0,242 maka $\mathrm{H}_{01}$ ditolak dan $\mathrm{H}_{\mathrm{a} 1}$ diterima yang artinya Perceived quality memiliki pengaruh positif terhadap Customer loyalty.

- Hipotesis 2:

- Bunyi hipotesis null $\left(\mathrm{H}_{0}\right)$ dan hipotesis alternatif $\left(\mathrm{H}_{\mathrm{a}}\right)$ adalah sebagai berikut:

- $\mathrm{H}_{02}$ : Brand loyalty tidak berpengaruh positif terhadap Customer loyalty.

- $\mathrm{H}_{\mathrm{a} 2}$ : Brand loyalty berpengaruh positif terhadap Customer loyalty.

- Pada pengujian hipotesis 2 diketahui $p$-value 0,015< alpha 0,05 dengan nilai beta sebesar 0,200 maka $\mathrm{H}_{02}$ ditolak dan $\mathrm{H}_{\mathrm{a} 2}$ diterima yang artinya Brand loyalty memiliki pengaruh positif terhadap Customer loyalty.

- Hipotesis 3:

- Bunyi hipotesis null $\left(\mathrm{H}_{0}\right)$ dan hipotesis alternatif $\left(\mathrm{H}_{\mathrm{a}}\right)$ adalah sebagai berikut:

- $\mathrm{H}_{03}$ : Brand association tidak berpengaruh positif terhadap Customer loyalty.

- $\mathrm{H}_{\mathrm{a} 3}$ : Brand association berpengaruh positif terhadap Customer loyalty.

- Pada pengujian hipotesis 3 diketahui $p$-value 0,002< alpha 0,05 dengan nilai beta sebesar 0,266 maka $\mathrm{H}_{03}$ ditolak dan $\mathrm{H}_{\mathrm{a} 3}$ diterima yang artinya Brand association memiliki pengaruh positif terhadap Customer loyalty.

- Hipotesis 4:

- Bunyi hipotesis null $\left(\mathrm{H}_{0}\right)$ dan hipotesis alternatif $\left(\mathrm{H}_{\mathrm{a}}\right)$ adalah sebagai berikut:

- $\mathrm{H}_{04}$ : Brand trust tidak berpengaruh positif terhadap Customer loyalty.

- $\mathrm{H}_{\mathrm{a} 4}$ : Brand trust berpengaruh positif terhadap Customer loyalty.

- Pada pengujian hipotesis 4 diketahui $p$-value 0,001< alpha 0,05 dengan nilai beta sebesar 0,282 maka $\mathrm{H}_{04}$ ditolak dan $\mathrm{H}_{\mathrm{a} 4}$ diterima yang artinya Brand trust memiliki pengaruh positif terhadap Customer loyalty.

\section{Pembahasan hasil penelitian}

Dari hasil uji hipotesis pada empat hipotesis penelitian terlihat bahwa Perceived quality memiliki pengaruh positif pada Customer loyalty, Brand loyalty memiliki pengaruh positif pada Customer loyalty, Brand association memiliki pengaruh positif pada Customer loyalty, Brand trust memiliki pengaruh positif pada Customer loyalty. Adapun pembahasan dari masing-masing hipotesis penelitian adalah sebagai berikut:

\section{Hipotesis 1: Perceived quality memiliki pengaruh positif terhadap Customer loyalty}

Pada hipotesis 1 diketahui $p$-value 0,007< alpha 0,05 dengan nilai beta sebesar 0,242 maka $\mathrm{H}_{01}$ ditolak dan $\mathrm{H}_{\mathrm{a} 1}$ diterima yang artinya Perceived quality memiliki pengaruh positif terhadap Customer loyalty. Hal ini menunjukkan bahwa Kualitas dari produk yang semakin baik maka dapat meningkatkan loyalitas pelanggan pada produk tersebut. Hal ini ditunjukkan dengan kualitas pelayanan dan produk reksadana Autolnvest di Commonwealth Bank yang baik sehingga saya akan membeli produk dari Commonwealth Bank.

\section{Hipotesis 2: Brand loyalty memiliki pengaruh positif terhadap Customer loyalty}

Pada hipotesis 2 diketahui $p$-value $0,015<$ alpha 0,05 dengan nilai beta sebesar 0,200 maka $\mathrm{H}_{02}$ ditolak dan $\mathrm{H}_{\mathrm{a} 2}$ diterima yang artinya Brand loyalty memiliki pengaruh positif terhadap Customer loyalty. Hasil ini menunjukkan bahwa kedalaman komitmen dan kesetiaan dari dalam diri pelanggan terhadap suatu produk dapat meningkatkan loyalitas pelanggan. Hal ini ditunjukkan dengan saya tetap memilih produk reksadana Autolnvest karena manfaat dari produk reksadana Autolnvest dan tetap menjalin hubungan bisnis dengan staff Commonwealth Bank.

Hipotesis 3: Brand association memiliki pengaruh positif terhadap Customer loyalty

Pada hipotesis 3 diketahui $p$-value 0,002< alpha 0,05 dengan nilai beta sebesar 0,266 maka $\mathrm{H}_{03}$ ditolak dan $\mathrm{H}_{\mathrm{a} 3}$ diterima yang artinya Brand association memiliki pengaruh 
positif terhadap Customer loyalty. Dengan asosiasi yang baik yang dimiliki oleh suatu produk maka dapat menciptakan peningkatan terhadap loyalitas pelanggan terhadap merek tersebut. Hal ini ditunjukkan dengan saya membeli Reksadana Autolnvest Commonwealth Bank karena dapat memenuhi harapan nasabah yang ingin berinvestasi.

\section{Hipotesis 4: Brand trust memiliki pengaruh positif terhadap Customer loyalty}

Pada hipotesis 4 diketahui $p$-value $0,001<$ alpha 0,05 dengan nilai beta sebesar 0,282 maka $\mathrm{H}_{04}$ ditolak dan $\mathrm{H}_{\mathrm{a} 4}$ diterima yang artinya Brand trust memiliki pengaruh positif terhadap Customer loyalty. Kepercayaan yang besar dari pelanggan terhadap kualitas suatu produk dapat meningkatkan loyalitas pelanggan terhadap merek tersebut. Hal ini ditunjukkan dengan saya tetap memilih Reksadana Autolnvest dari Commonwealth Bank meskipun ada produk pesaing dengan jenis yang sama.

\section{G. Kesimpulan}

Berdasarkan uraian dan análisis yang telah dikemukakan pada bab sebelumnya, maka simpulan yang diperoleh dari penelitian ini adalah hasil pengujian hipótesis menurut kualifikasi menunjukkan bahwa Brand trust memiliki pengaruh positif terhadap Customer loyalty memiliki nnilai beta terbesar yaitu sebesar 0,282 dengan nilai signifikasi sebesar 0,001 . Kepercayaan yang besar dari pelanggan terhadap kualitas suatu produk dapat meningkatkan loyalitas pelanggan terhadap merek tersebut. Hal ini ditunjukkan dengan kesetiaan pelanggan untuk membeli produk dengan merek yang sama walaupun banyak produk pesaing dengan jenis yang sama.

\section{H. Daftar Pustaka}

Aaker, David, 1991, Managing Brand Equity; Capitalizing on The Value of Brand Name, Free

Press, New York.

Aaker, D.A. (2004), "Leveraging Corporate Brand", California Management Review, Vol. 46 No. 3 Pp 6-18.

Abdullah, Mokhtar; Al-Nasser, Amjad D; Husain, Nooreha. (2000), "Evaluating functional relationship Between image, customer satisfaction, and customer loyalty using general

maximum entropy", Total Quality Management, Vol. 11, pp. 4-6.

Andrews, M. and Kim, D. (2007), "Revitalising suffering multinational brands: an empirical study", International Marketing Review, Vol 24 No. 3, pp. 350-372.

Bertea, P.E. and Moisescu, O.I. (2010), "Investigating the Role of Brand Awareness in Reducing the Perceived Risk Associated to online Buying of Tourism Services", International

Conference Marketing - from information to decision, Vol. 3, pp. 9-18.

Bravo, R., Fraj, E, Martinez, E. (2007), "Intergenerational influences on the dimensions of young customer - based brand equity young consumers", Insight and ldeas for

Responsible

Marketers, Vol. 8 No.1, pp.58-64.

Chahal, H. and Bala, M. (2010), "Confirmatory study on brand equity and brand loyalty: A special look at the impact of attitudinal and behavioural loyalty", Vision, Vol. 14 No (1), pp. 1-12.

Chen, A.C.H. (2001), "Using free association to examine the relationship between the characteristics of brand association and brand equity", Journal of Product \& Brand Management, Vol. 10 No. 7, pp. 439 - 451

Coop, W.F. (2002), Brand image of MBA business schools in South Africa as driver of customer-based brand equity. Unpublished Master's dissertation, Cape Technikon, Cape Town.

Davis, S.M. (2002), Brand Asset Management: Driving Profitable Growth through Your Brands, San Francisco, Josey Bass. 
Djakeli, K. (2012), Matrix of Brand Awareness and a Positive Image as a Success Factor in

Political PR", Scientific Journal in Humanities, Vol. 1 No (1), pp. 31-35.

Faircloth, J.B., Capella, L. M., \& Alford, BL. (2001), "The effect of brand attitude and brand image on brand equity", Journal of Marketing Theory and Practice, 9 (3), pp. 61 74.

Farquhar, P. (2003), "Editorial: uncovering brand gremlins and other hidden perils", Journal of Brand Management, Vol. 10 No. 6, pp. 388-92.

Fayrene, C.Y.L. and Lee, G.C., (2011), "Customer based brand equity: A literature review",

Journal of Arts Science \& Commerce, Vol. 2 No. 1, pp. 33-42

Gill, M.S. and Dawra, J. (2010), "Evaluating Aaker's sources of brand equity and the mediating

role of brand image" Journal of Targeting, Measurement and Analysis for Marketing,

Sep-Dec 2010, Volume: 18 No. 3 pp. 189-198

Gounaris, S., Stathakopoulos, V. (2004), "Antecedents and Consequences of Brand Loyalty:

An Empirical Study", Journal of Brand Management Vol. 11, No. 4, pp. 283-306.

Holland, J. and Baker, S.M. (2001), "Customer participation in creating site brand loyalty", Jounal of Interactive Marketing, Vol. 15 No. (4), pp.34-45.

Hermawan, A. (2006). Penelitian Bisnis Paradigma Kuantitatif. Jakarta: PT. Gramedia Widia

Sarana Indonesia.

Hung, C.H. (2008), "The effect of brand image on public relations perceptions and customer

loyalty", International Journal of Management, Vol. 25 No. (2), pp. 237-246.

James, D. (2005), "Guilty Through Association: Brand Association transfer to brand

Alliances”, Journal of Consumer Marketing, Vol. 22 No. 1, pp. 14-25.

Jasfar, F. 2005, Manajemen Jasa Pendekatan Terpadu, Penerbit Ghalia Indonesia, Cetakan

Pertama.

Jansen, H.M. and Hansen, T. (2006), "An empirical examination of brand loyalty", The Journal

of Product and Brand Management, Vol. 15 No. 7, pp. 442 - 449.

Kayaman, R. and ARASLI, h. (2007), "Customer based brand equity: evidence from the hotel

industry", Managing Service Quality, Vol. 17 No. 1, pp. 92-109.

Keller, Kevin L. (2003), Strategic Brand Management: Building, Measuring, and Managing

Brand Equity (second ED.). Upper Saddle River, NJ: Prentice Hall.

Keller, K.L. (2008) Strategic Brand Management: Building, Measuring and Managing Brand

Equity, Prentice Hall, Upper Saddle River, New Jersey.

Kotler, Ph. (1991), Marketing Management, Prentice Hall International.

Kotler, P. and Keller, K.L. 2008. Manajemen Pemasaran. Jilid Satu, Edisi Keduabelas,

Cetakan Ketiga, Penerbit Indeks.

Moisescu, O.I. (2011), "A Conceptual Review on Building, Managing and Assessing Brand Loyalty", Review of Economic Studies and Research Virgil Madgearu, Vol. 4 No. 1, pp. $67-87$.

Moisescu, O.I., Allen, b. (2010), "The Relationship Between Dimensions of Brand Loyalty. An Empirical Investigation Among Romanian Urban Consumers",

Management \&Marketing, vol. 5, No. 4. 
Moisescu, O.I., Vu, D.A (2011), "A Conceptual Review on Building, Managing, and Accessing

Brand Loyalty", Review of Economic Studies and Research Virgil Madgearu, Vol. 4 No.1, pp 67-87.

Morton, J., 1994, "Predicating brand preference", Market Management, Vol.2 No. (4), pp. 32-44.

Nandan, S. (2005), "An exploration of the brand identity-brand image linkage: A

communications Perspective". Brand Management, Vol. 12 No. (4), pp. 264-278

Pappu, R., Quester, P.G., and Cooksey, R.W. (2006), "Consumer-based brand equity and country of origin relationships: Some empirical evidence", European Journal of

Marketing, Vol.40 No. 5/6, pp. 696-717.

Peng, W.T. (2006), "The relationship among brand awareness, brand image and brand loyalty-

an empirical study of domestic rice wine market", Unpublished master thesis, National

Dong Hwa University, Taiwan.

Rangkuti, F. 2004, Riset Pemasaran. Cetakan Kelima. PT. Gramedia Pustaka Utama. Jakarta.

Rangkuti, F. (2006). Measuring Customer satisfaction. PT. Gramedia Pustaka Utmaa, Jakarta.

Rios, R.E. and Riquelme, H.E. (2008), "Brand equity for online companies", Marketing Intelligence \& Planning, Vol. 26 Iss: 7, pp. $719-742$

Rundle-Thiele, S. and Mackay, M.M (2001), "Assessing the performance of brand loyalty measures", Journal of Services Marketing, Vol. 15 Iss: 7, pp. 529-546.

Sekaran, U. 2006, Metodologi Penelitian untuk Bisnis, Edisi 4, Buku 2, Jakarta: Salemba Empat.

Severi, E. and Ling, K.C. (2013), "The Mediating Effects of Brand Association, Brand Loyalty,

Brand Image and Perceived Quality on Brand Equity", Asian Social Science; Vol. 9,

No. 3, pp. $125-137$.

Shukla, P. (2009), "Impact of contextual factors, brand loyalty and brand switching on purchase

Decisions", The Journal of Consumer Marketing, Vol. 26 No. 5, pp. 348 - 357.

Sugiyono, 2007. Metode Penelitian Bisnis. Bandung: CV Alfabeta.

Tjiptono, F. 2004. Manajemen Jasa, Andi. Yogyakarta.

Tung, F. (2010), “Exploring Customer Satisfaction, Perceived Quality and Image: An empirical

Study in the Mobile Services Industry", The Business Review, Vol. 14 No. (2), pp. 63 -69.

Uggla, H (2004), "The brand association base: A conceptual model for strategically leveraging

brand Equity", The Journal of Brand Management, November, Vol. 12, No. 2 pp. 105 $-123$.

Uggla, H. (2006), "The corporate brand association base: A conceptual model for the creation

of Inclusive brand architecture", European Journal of Marketing, Vol. 40 No. 7/8, pp.

$785-802$.

Van. Osselaer, S.M.J. and Janiszewski, C. (2000), "Two Ways of Learning Brand Association",

Journal of Consumer Research, Vol. 28, pp. 202 - 223.

Wang, X. And Yang, Z. (2010), "The Effect of Brand Credibility on Consumer's Brand Purchase Intention in Emerging Economies: The Moderating Role of Brand Awareness

and Brand Image “, Journal of Global Marketing, Vol. 23 No. 3, pp. 177-188. 
Yaseen, N., Tahira, M. and Anwar, A. (2011), "Impact of Brand Awareness, Perceived Quality and Customer Loyalty on Brand Profitability in Purchase Intention: A Resellers' View", Interdisclipinary Journal Contemporary Research in Business, Vol. 3 No. 8, pp.833 - 839.

Yasin, N.M., Noor, M.N. \& Mohamad, O. (2007), "Does Image of country origin matter to brand

equity?', Journal of Product \& Brand Management Vol. 78, 16, pp. 38-48.

Youl-Ha, H. (2008), "An empirical test if a proposed customer satisfaction in e-services", The

Journal of Services Marketing, Vol. 22 No.5, pp. 305-408.

Zeithaml VA (1988), Consumer perceptions of price, quality, and value means-end model and

synthesis of evidence", Journal of Marketing, 52, (July), pp. 2-22. 